\title{
PENGEMBANGAN MULTIMEDIA SISTEM BAHAN BAKAR MOTOR DIESEL UNTUK SISWA SEKOLAH MENENGAH KEJURUAN PADA KOMPETENSI SISTEM INJEKSI BAHAN BAKAR DIESEL
}

\author{
Eko Budi Utomo ${ }^{1}$, Dwi Widjanarko ${ }^{2}$, Winarno Dwi Rahardjo ${ }^{3}$ \\ ${ }^{1,2,3}$ Pendidikan Teknik Otomotif Universitas Negeri Semarang \\ email: $\underline{\text { ir43ekobudi@gmail.com }}$
}

\begin{abstract}
Abstrak
Tujuan penelitian ini adalah untuk menguji kevalidan dan keefektifan multimedia pembelajaran sistem injeksi bahan bakar motor diesel. Penelitian ini menggunakan metode Research and Development / $R \& D$ dengan model pengembangan 4D model yang terdiri dari tahap Define (pendefinisian), tahap Design (perancangan), tahap Develop (pengembangan), disseminate (penyebaran). Uji coba produk dilakukan dengan desain eksperimen (before-after) yaitu dengan cara membandingkan hasil belajar sebelum dan sesudah memakai multimedia. Hasil penelitian menunjukkan bahwa multimedia yang dikembangkan sangat valid yang didasarkan pada penilaian dari validator ahli media dan valid berdasarkan penilaian ahli materi. Multimedia sistem injeksi bahan bakar motor diesel juga efektif diterapkan sebagai media dalam pembelajaran dengan hasil rata-rata belajar siswa (post-test) sebesar 78,92 lebih tinggi dari pada hasil belajar siswa (pre-test) sebesar 48,06. Hal ini terbukti dari hasil uji $\mathrm{t}$ bahwa ada perbedaan hasil belajar yang signifikan sebelum dan setelah menggunakan multimedia tersebut.
\end{abstract}

Kata Kunci : multimedia, motor diesel, sistem injeksi

\begin{abstract}
The purpose of this research is to test the validity and the effectiveness of diesel fuel injection system multimedia. This research is a Research and Development $(R \& D)$ witd $4 D$ development model consisting of define, design, develop, and disseminate. Product field testing was conducted with before-after experimental design and comparing the students' achievment before and after using multimedia. The results showed that the multimedia is very valid and valid according to multimedia expert and automotive expert judgements. The diesel fuel injection system multimedia was also effectively applied as a learning media. This was indicated by the average post-test score of 78.92 being higher than the average pretest score of 48.06. The t-test results indicates that there is a significant difference learning outcomes before and after using the multimedia.
\end{abstract}

Keywords : multimedia, diessel motor, injection system 


\section{PENDAHULUAN}

Perkembangan kualitas dan kuantitas pembelajaran harus dilakukan oleh lembaga pendidikan, salah satunya adalah Sekolah Menengah Kejuruan (SMK). Selaras dengan hal ini, SMK Muhammadiyah Boja turut andil membangun sistem yang terbarukan guna menghasilkan lulusan yang berkualitas melalui penekunan isi pengajaran yang berbentuk konsep/teori. Peningkatan kualitas pembelajaran salah satunya melalui pengajaran yang keterampilan yang dilakukan melalui kegiatan praktikum (Amin,2015:484).

Guna mewujudkan pembelajaran yang menarik dibutuhkan media pembelajaran yang menarik pula. Menurut Musfiqon (2012:28) Media pembelajaran adalah alat bantu berupa fisik atau nonfisik yang sengaja digunakan sebagai perantara antara guru dan siswa dalam memahami materi pembelajaran agar lebih efektif dan efesien. Berdasarkan hasil observasi, pada kenyataan di lapangan SMK Muhammadiyah 2 Boja masih terkendala sarana dan prasarana pembelajaran berupa terbatasnya media LCD proyektor, dimana media tersebut sebagai sarana pendukung terhadap penggunaan multimedia yang akan dikembangkan, banyaknya stand peraga yang tidak berfungsi serta minimnya sumber bacaan buku yang relevan, dimana pada saat proses pembelajaran media yang digunakan hanya power point. Merujuk permasalahan dan uraian dapat ditarik kesimpulan untuk melakukan pengembangan multimedia khususnya pada materi sistem injeksi bahan bakar motor diesel.

Sistem bahan bakar (fuel system) pada motor diesel memiliki peranan yang sangat penting dalam menyediakan dan mensuplai sejumlah bahan bakar yang dibutuhkan sesuai dengan kapasitas mesin, putaran motor dan pembebanan motor. Motor diesel tidak menggunakan sistem pengapian sebagai mana motor bensin. Motor diesel hanya menghisap udara segar dan dikompresikan sehingga suhu dan tekanannya naik. Selanjutnya bahan bakar diinjeksikan dengan udara yang sudah memiliki suhu dan tekanan tinggi menjelang akhir langkah kompresi (Kristanto, 2015:144).

Komponen sistem bahan bakar motor diesel mencakup tangki bahan bakar, saringan bahan bakar dan water sedimenter, pompa tangan (priming pump), pompa injeksi, automatic timer, selonoid, governor, dan Injection Nozzel (Rabiman dan Arifin, 2011). Dalam rangka penguatan kompetensi siswa mengenai system bahan bakar motor diesel, maka konsep, komponen, cara kerja, dan hal lain yang terkait dengan system bahan bakar motor diesel, maka dilakukan pengembangan multimedia system bahan bakar motor diesel sebagai media dalam pembelajaran.

Menurut Arsyad (2007:3) "kata media berasal dari bahasa latin medius yang secara harfiah berarti tengah, perantara atau pengantar." Sedangkan dalam bahasa arab "media adalah perantara atau pengantar pesan dari pengirim kepada penerima pesan. Menurut Musfiqon (2012:28) media pembelajaran adalah alat bantu berupa fisik atau nonfisik yang sengaja digunakan sebagai perantara anatara guru dan siswa dalam memahami materi pembelajaran agar lebih efektif dan efesien. Kustandi dan Sutjipto (2011:8) menyampaikan bahwa media pembelajaran adalah alat yang dapat membantu proses belajar mengajar dan berfungsi untuk memperjelas makna yang disampaikan untuk mencapai tujuan pembelajaran. Sehingga dapat simpulkan bahwa, media pembelajaran merupakan alat bantu atau sarana yang dipakai pendidik untuk dapat digunakan untuk merangsang pemikiran dan perhatian peserta didik sehingga dapat mendorong terjadinya proses belajar yang efektif guna mencapai tujuan pembelajaran. 
Pembelajaran akan menjadi lebih baik jika dalam proses belajar mengajar melibatkan banyak media yang digunakan (multimedia). Menurut Rusman et al. (2011:65) "multimedia berbasis komputer merupakan jenis media yang secara virtual dapat menyediakan respons yang segera terhadap hasil belajar yang dilakukan oleh siswa." Sedangkan menurut Munir (2013:2) "multimedia berarti berhubungan dengan penggunaan lebih dari satu macam untuk menyajikan informasi”. Kustandi dan Sutjipto (2011:68) mengatakan bahwa multimedia adalah alat bantu penyampaian pesan yang menggabungkan dua elemen atau lebih media, meliputi teks, gambar, grafik, foto, suara, film, dan animasi secara terintegrasi.

Multimedia terbagi menjadi dua kategori, yaitu multimedia linier dan interaktif. Multimedia linier adalah multimedia yang tidak dilengkapi dengan alat pengontrol apapun yang dapat di oprasikan oleh pengguna. Multimedia ini berjalan sekuensial atau (berurutan) contohnya TV dan film. Sedangkan multimedia interaktif adalah suatu media yang dilengkapi dengan alat pengontrol yang dapat dioperasikan oleh pengguna, sehingga pengguna dapat memilih apa yang dikehendaki untuk proses selanjutnya. Contoh multimedia interaktif adalah pembelajaran interaktif, aplikasi game, dan lain-lain (Kustandi dan Sutjipto 2011:68-69).

Multimedia mempunyai banyak aplikasi untuk menampilkan berbagai animasi dan simulasi. Peserta didik akan sangat tertolong dengan multimedia interaktif dalam memahami konsep yang abstrak menjadi lebih konkrit. Selanjutnya konsep yang sudah konkrit tersebut akan membuat peserta didik lebih bermakna dalam pembelajarannya (Munir 2013:115). Dalam pembelajaran, multimedia memang memiliki banyak keunggulan dalam memfasilitasi siswa dalam belajar. Beberapa hasil penelitian menunjukkan bahwa multimedia dapat meningkatkan hasil belajar. Penelitian sebelumnya pernah dilakukan mengenai pengembangkan media pembelajaran pompa injeksi tipe VE Distributor berbasis flash player. Pembuatan media pembelajaran pompa injeksi tipe VE distributor berbasis flash player dalam mata pelajaran bahan bakar dimaksudkan telah valid dan dapat diimplementasikan ke kalangan yang lebih luas seperti ke guru lain atau ke sekolah lain (Irawan 2014).

Selanjutnya penelitian yang dilakukan oleh Sa'dullah (2014). Mengembangkan multimedia penggunaan injector tester untuk meningkatkan hasil belajar pengujian injektor pada kendaraan EFI. Pembuatan multimedia dimaksudkan untuk meningkatkan hasil belajar mahasiswa pada kompetensi penggunaan injektor tester untuk pemeriksaan injektor EFI. Nilai ratarata yang diperoleh siswa sebelum menggunakan multimedia adalah 49,03 dan meningkat menjadi 84,60 setelah menggunakan multimedia.

\section{METODE PENELITIAN}

Metode penelitian menggunakan metode Research and Development / $R \& D$ dengan model pengembangan 4D model yang terdiri dari tahap Define (pendefinisian), tahap Design (perancangan), tahap Develop (pengembangan), disseminate (penyebaran) . Analisis evaluasi hasil belajar dilakukan secara eksperimen. Eksperimen dilakukan dengan cara membandingkan dengan keadaan sebelum dan sesudah pembelajaran menggunakan media baru (beforeafter). Berikut adalah alur pengembangan yang digunakan dalam penelitian dan pengembangan multimedia sistem injeksi bahan bakar motor diesel. 


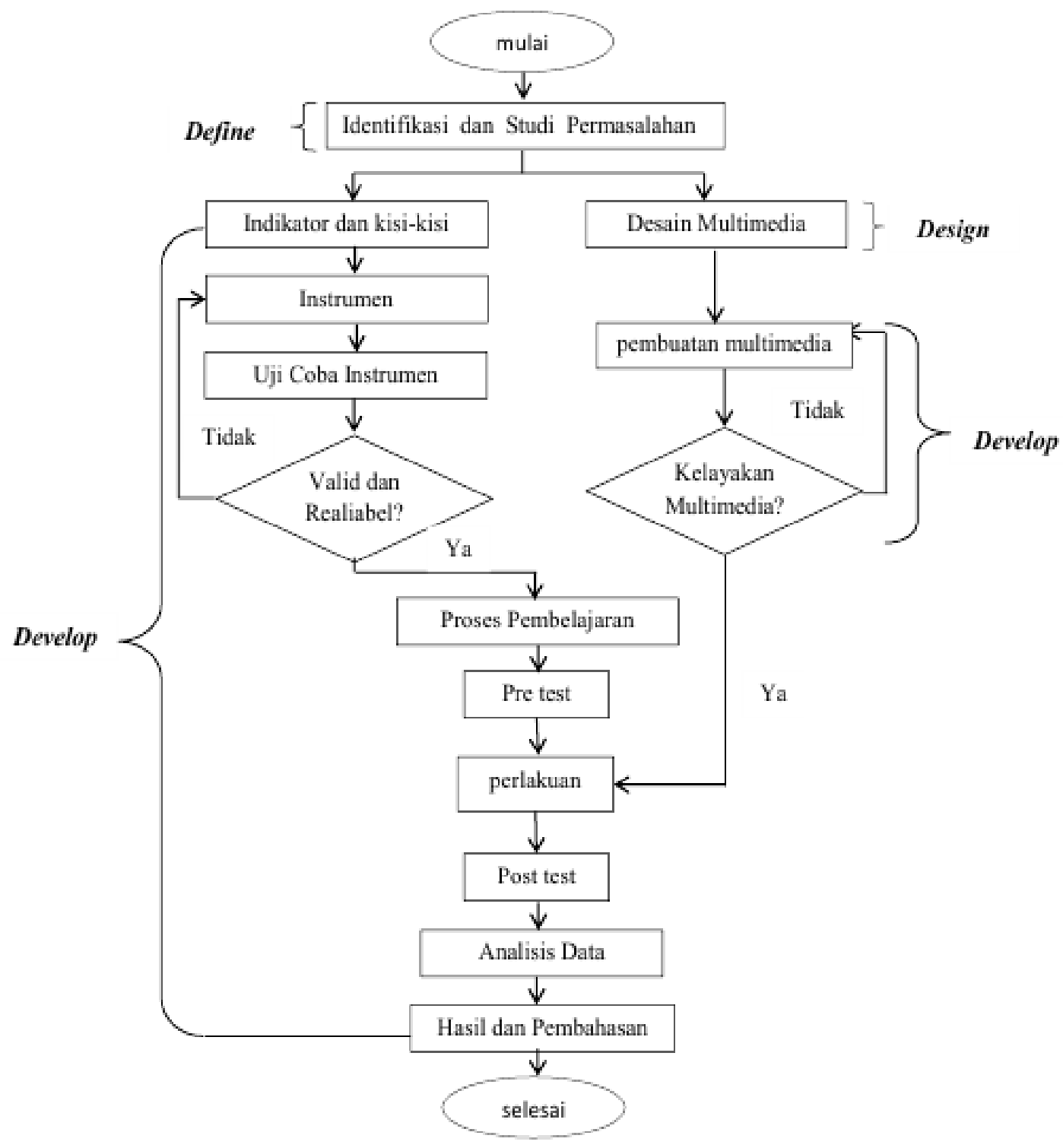

Gambar 1. Tahap pengembangan model 4D

Untuk mengetahui bahwa hasil belajar mahasiswa dari yang diberi pembelajaran sebelum menggunakan metode mengajar baru, dengan pembelajaran menggunakan multimedia lebih baik dibanding dengan sebelum menggunakan multimedia dengan cara eksperimen. Eksperimen dapat dilakukan dengan cara membandingkan dengan keadaan sebelum dan sesudah pembelajaran menggunakan metode mengajar baru (before-after). Dalam hal ini adalah kelompok pre-test dan post-test Sugiyono (2015:74).

Subyek dalam penelitian ini ditujukan pada siswa kelas XII TKR 1 yang mengikuti mata pelajaran produktif pada kompetensi sistem injeksi bahan bakar diesel. Data hasil belajar siswa diperoleh sebelum menggunakan pembelajaran dengan menggunakan multimedia (pre-test) dan hasil belajar siswa setelah menggunakan pembelajaran dengan menggunakan multimedia (post-test). Untuk 
mengetahui keefektifan hasil evaluasi pembelajaran dalam penelitian menggunakan multimedia sistem injeksi bahan bakar diesel, maka dilakukan uji t-berpasangan dengan prasyarat uji normalitas dan uji homogenitas terlebih dahulu.

\section{HASIL PENELITIAN}

Pada tahap pertama yaitu tahap Define, adapun tahapannya adalah sebagai berikut : a. Analisis awal-akhir, diperoleh kajian tentang masalah yang dihadapi guru dalam meningkatkan hasil prestasi belajar siswa meliputi dari kurangnya tenaga pengajar khususnya pada saat praktek, kurangnya sarana media pendukung dalam pembelajaran berupa multimedia kemudian stand peraga pembelajaran yang minim dan tidak bisa difungsikan sebagaimana mestinya. Sedangkan pada proses pembelajaran guru hanya memanfaatkan buku dengan metode ceramah sehingga siswa sulit dalam memahami isi materi, b. Analisis mahasiswa diperoleh kajian bahwa siswa yang mengantuk, tidak fokus pada saat pembelajan berlangsung, karena memang hanya buku yang digunakan dalam menjelaskan materi, sehingga siswa merasa jenuh, c. Analisis tugas diperoleh kajian siswa kurang tanggap pada saat praktek, terutama memahami isi materi berupa fungi dan dan cara kerja komponen. Karena dalam memahami materi yang kompleks terutama bagian cara kerja, siswa hanya diberikan penjelasan dengan metode ceramah, d. Analisis konsep diperoleh kajian bahwa guru masih kurang maksimal dalam menyampaikan materi yang mana hanya mengandalkan buku, sedangkan stand peraga yang masih belum bisa dimanfaatkan, e. Penentuan tujuan pembelajaran diperoleh kajian dengan materi yang begitu kompleks dengan waktu yang relatif sedikit guru harus mampu memberikan pembelajaran yang maksimal, Dengan adanya multimedia yang dibuat guru dapat menerangkan materi secara maksimal dengan waktu yang relatif sedikit. Menyikapi hal tersebut perlu dikembangkan media pembelajaran untuk membantu guru dalam menyampaikan pelajaran dengan metode ceramah dan memvisualisasikan materi sistem injeksi bahan bakar motor diesel yang kompleks

Tahap kedua yang dilakukan peneliti yaitu design (perancangan) multimedia sistem injeksi bahan bakar diesel. Dalam perencanaan ini tahap awal yang dilakukan adalah:1. Penyusunan tes, penyusunan instrumen yang berupa tes digunakan untuk mengukur kemampuan dasar dan pencapaian atau prestasi. adalah menyusun instrumen soal tes, instrumen validasi ahli media dan materi, 2. Pemilihan media, pada tahap ini multimedia dibuat dengan software Macromedia Flash Professional 8, 3.Pemilihan format, pemilihan format berkaitan erat dengan pemilihan media, format yang dipilih sesuai dengan kisikisi penilaian pada angket validator, di antaranya adalah menentukan layout, gradasi warna yang digunakan, desain tampilan, 4. Desain awal, tahapan pada desain awal adalah membuat desain awal antara lain: 1.membuat desain isi media, 2.membuat desain story board, 3.desain diagram alir, 4.desain pada multimedia ( halaman opening, halaman kompetensi, halaman materi, halaman evaluasi, halaman profil).

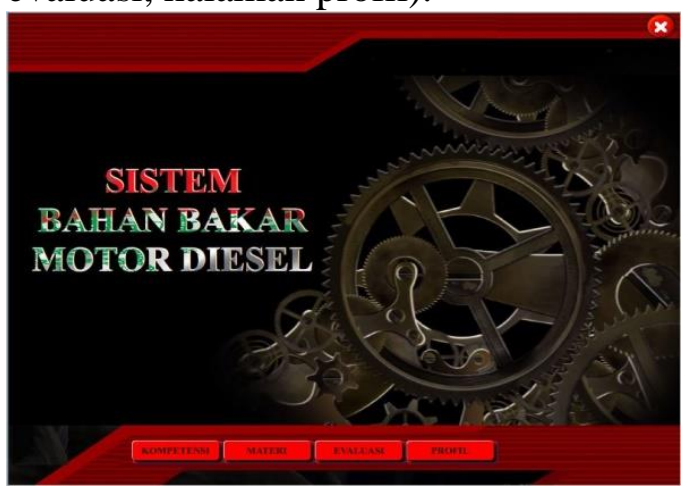

Gambar 2. Desain tampilan multimedia 
Tahap ketiga yang dilakukan peneliti adalah Develop ( Pengembangan) peneliti fokus dalam dua kegiatan pengembangan yaitu: validasi multimedia oleh ahli/pakar dan mengadakan uji coba terbatas. Uji kelayakan dilakukan oleh 2 orang ahli media dan 2 orang ahli materi. Berdasarkan analisis data hasil penelitian, penilaian dari ahli media I dan II adalah sebesar 87,5, dengan kriteria kelayakan "Sangat Layak" berada pada presentase 81\%-100\% (Arikunto, 2013: 281).

Tabel 1. Hasil uji validasi Ahli media

\begin{tabular}{lllll}
\hline No. & Aspek Penilaian & Validator 1 & Validator 2 & Kelayakan \\
\hline 1. & Tampilan & 85 & 80 & $82,5 \%$ \\
2. & Kualitas teknis & 100 & 85 & $92,5 \%$ \\
\hline Rerata & & & $87,5 \%$ \\
\hline
\end{tabular}

Berdasarkan penilaian ahli materi hasil validasi multimedia sistem injeksi bahan bakar diesel oleh ahli materi I dan II adalah sebesar $\mathbf{7 5 , 4 5 \%}$ dengan klasifikasi kelayakan "Layak" berada pada presentase 61\%-80\% (Arikunto, 2013: 281).

Tabel 2. Hasil uji validasi ahli media

\begin{tabular}{llll}
\hline \multicolumn{1}{c}{ Aspek Penilaian } & Validator 1 & Validator 2 & Kelayakan \\
\hline $\begin{array}{l}\text { Memahami materi pada } \\
\text { multimedia dengan kajian } \\
\text { teori }\end{array}$ & 69,09 & 81,81 & $75,45 \%$ \\
\hline
\end{tabular}

Untuk mengetahui keefektifan hasil evaluasi pembelajaran dalam penelitian menggunakan multimedia sistem injeksi bahan bakr motor diesel, maka dilakukan uji t-berpasangan dengan prasyarat uji normalitas dan uji homogenitas terlebih dahulu.
Uji normalitas digunakan untuk mengetahui apakah data yang dihasilkan berdistribusi secara normal atau tidak. Hipotesis nol pada uji normalitas ini adalah data berdistribusi normal. Hipotesis nol diterima apabila $X^{2}{ }_{\text {hitung }}<$ $\mathrm{X}_{\text {tabel. }}^{2}$.

Tabel 3. Hasil Uji Normalitas Data Hasil Pre-test dan Post-test

\begin{tabular}{lcccc}
\hline \multicolumn{1}{c}{ Data } & $x^{2}$ Hitung & Dk & $x^{2}$ Tabel & Kriteria \\
\hline Before & 7,9182 & 5 & 11,070 & Normal \\
After & 4,69095 & 5 & 11,070 & Normal \\
\hline
\end{tabular}

Uji hipotesis merupakan uji paling akhir, diuji untuk mengetahui ada tidaknya perbedaan rata-rata antara Pre-test dan Post-test. Uji yang digunakan adalah uji-t berpasangan.

Tabel 5. Hasil Uji Perbedaan Dua Rata-Rata antara pre-test dan post-test

\begin{tabular}{lllllll}
\hline No. & Data & Rata-rata & $\mathrm{t}$ hitung & $\mathrm{t}$ tabel & $\mathrm{M}_{\mathrm{d}}$ & Simpulan \\
\hline 1 & Before & 48,0675 & 13,150 & 1,70 & 30,85 & Signifikan \\
2 & After & 78,928 & & & & \\
\hline
\end{tabular}


Berdasarkan data pada table di atas, maka nilai pretes dan postes berbeda signifikan sehingga multimedia efektif digunakan dalam pembelajaran.

\section{Pembahasan}

Berdasarkan penilaian oleh ahli media pembelajaran ditinjau dari aspek kualitas tampilan dan aspek kualitas teknis mendapatkan hasil penilain media yang Sangat Layak. Sedangkan dari penilaian oleh ahli materi pembelajaran ditinjau dari aspek memahami materi dalam multimedia dengan kajian teori mendapatkan hasil penilain media yang Layak. Hasil penilaian oleh ahli media materi dapat dijabarkan secara terperinci dalam dua pengelompokan yaitu mana penilaian yang telah layak dan mana penilaian yang masih kurang layak sehingga untuk ke depan media pembelajaran Berbasis Multimedia untuk mata pelajaran sistem injeksi bahan bakar motor diesel dapat dikembangkan lebih baik lagi. adapun perbaikan pada ahli media diantaranya pewarnaan dan kerterbacaan teksa sedangankan untuk ahli materi penambahan gambar pada kontruksi dan ciri pompa. Sehingga dapat ditarik kesimpulan media pembelajaran Berbasis Multimedia secara keseluruhan dikategorikan layak dengan kualitas produk baik, dan dapat digunakan sebagai media pembelajaran yang layak digunakan.

Berdasarkan hasil peningkatan nilai siswa yang diperoleh antara sebelum dan sesudah menggunakan multimedia menunjukkan hasil yang sangat signifikan. Dari keterangan tersebut media pembelajaran Berbasis Multimedia sangat efektif untuk menjelaskan fungsi dan cara kerja komponen. Hal ini terbukti dengan adanya multimedia pada proses bembelajaran hasil nilai prestasi siswa meningkat, bukan hanya terbatas pada peningkatan prestasi, siswa juga cenderung lebih aktif dan terangsang untuk bertanya berkaitan dengan materi yang diajarkan. Berdasarkan dari hasil penilain tersebut dapat disimpulkan bahwa media pembelajaran berbasis Multimedia sangat layak digunakan dan efektif dalam meningkatkan prestasi belajar siswa pada materi sistem injeksi bahan bakar motor diesel.

Hasil tersebut dapat disebabkan

karena kelebihan yang dimiliki multimedia. Ini sejalan dengan Kustandi dan Sutjipto (2011:68-69) bahwa "multimedia interaktif adalah suatu media yang dilengkapi dengan alat pengontrol yang dapat dioperasikan oleh pengguna, sehingga pengguna dapat memilih apa yang dikehendaki untuk proses selanjutnya". Sedangkan manfaat untuk siswa adalah memberikan kemudahan dalam memahami materi pada saat proses pembelajaran berlangsung. Hal ini juga sejalan dengan pendapat Rusman et al. (2011:65) "multimedia berbasis komputer merupakan jenis media yang secara virtual dapat menyediakan respons yang segera terhadap hasil belajar yang dilakukan oleh siswa".

Dalam penelitian lain, Munir (2013:115) pendapat bahwa Multimedia pembelajaran dapat diartikan sebagai aplikasi multimedia yang digunakan dalam proses pembelajaran dengan kata lain digunakan untuk menyalurkan pesan (pengetahuan, keterampilan dan sikap) serta dapat merancang pilihan, perasaan, perhatian dan kemauan peserta didik, sehingga secara sengaja proses belajar itu terjadi, bertujuan dan terkendali. Kemudian hasil penelitian Sa'dullah (2014) "bahwa ada peningkatan hasil belajar yang signifikan antara mahasiswa sebelum diberikan multimedia pembelajaran dan setetelah diberikan multimedia pembelajaran kompetensi penggunaan injector tester untuk pemeriksaan injektor EFI". Berkaitan hasil penelitian yang sudah ada dapat disimpulkan 
bahwa media pembelajaran Berbasis Multimedia dapat membantu untuk meningkatkan prestasi secara keseluruhan terbukti dengan hasil ratarata nilai prestasi siswa lebih baik antara yang menggunakan media dibandingkan dengan tanpa menggunakan media. Kesimpulan ini sejalan dengan tujuan awal dari penelitian yaitu media pembelajaran Berbasis Multimedia dapat meningkatkan hasil prestasi siswa.

\section{PENUTUP Simpulan}

Simpulan dari penelitian ini : (1). Kelayakan media pembelajaran Berbasis Multimedia secara keseluruhan dikategorikan layak dengan kualitas produk baik, sehingga media pembelajaran Berbasis Multimedia pada materi sistem injeksi bahan bakar motor diesel dapat digunakan sebagai media pembelajaran yang layak digunakan. Multimedia pembelajaran dinyatakan layak berdasarkan uji kelayakan produk menurut ahli media dengan persentase kelayakan 87,50\%, penilain dari ahli materi dengan persentase $75,45 \%$. (2). Multimedia yang dikembangakan efektif karena ada peningkatan prestasi belajar siswa yang signifikan pada kelas XII TKR 4 SMK Muhammadiyah 2 Boja, setelah mengikuti proses pembelajaran menggunakan Multimedia sistem injeksi bahan bakar diesel. Adapun peningkatan prestasi tersebut berbeda secara siginfikan antara sebelum dan sesudah menggunakan multimedia yaitu pada kelas XI TKR 4. Dengan rata-rata hasil prestasi belajar siswa sebelum menggunakan multimedia sebesar 48,06. Sedangkan untuk hasil Prestasi belajar rata-rata siswa setelah menggunakan multimedia sebesar 78,92.

\section{DAFTAR PUSTAKA}

Amin, M. 2013. Pengaruh Pembelajaran Responsi Pra Praktikum Dan Jobsheet Terpadu Terhadap Hasil Belajar Mahasiswa Pada Praktik Pengukuran Listrik. Medan. Jurnal Pendidikan Teknologi dan Kejuruan. Vol 22/4, No. 484 $-493$.

Arikunto, Suharsimi. 2013. Dasardasar Evaluasi Pendidikan. Jakarta: PT Bumi Aksara.

Arikunto, Suharsimi. 2013. Prosedur Penelitian Suatu Pendekatan Praktik. Jakarta: PT Rineka Cipta.

Arsyad, A. 2007. Media Pembelajaran. Jakarta : PT. Raja Grafindo Persada.

Irawan, D. 2014. Pengembangan media pembelajaran pompa injeksi tipe $V E$ distributor berbasis flash player. Semarang. Jurnal Pendidikan Teknik Mesin. Vol 1, No. 3 .

Kustandi, C. dan Sutjipto, B. 2011. (eds) Media Pembelajaran "Manual dan Digital". Bogor: Ghalia Indonesia.

Kristanto, P. 2015. Motor Bakar Torak. Yogyakarta: CV.Andi Offset.

Munir. 2015. Multimedia Laerning. Jakarata: PT Bumi Aksara.

Musfiqon. 2012. Pengembangan Media dan Sumber Pembelajaran. Jakarta: PT Prestasi Pustakaraya.

Rabiman. dan Arifin, Z. 2011. Sistem Bahan Bakar Motor Diesel. Yogyakarta: Graha Ilmu. 
Rusman. Kurniawan, D., dan Riyana, C. 2011. Pembelajaran Berbasis Teknologi Informasi dan Komunikasi. Jakarta : Rajawali Pers.

Sa'dullah, M. 2014. Pengembangan multimedia penggunaan injektor tester untuk meningkatkan hasil belajar pengujian injektor pada kendaraan EFI. Semarang. Jurnal Pendidikan Teknik Mesin. Vol 1, No. 3

Sugiyono. 2015. Metode Penelitian dan Pengembangan (Reserch and Development/ $R \& D)$. Bandung: Alfabeta. 